\title{
Managing Up the Hierarchy: US Correctional Institutions and Differences in the Use of Influence Strategies
}

\author{
Anna B. Kayes \\ Associate Professor of Management \\ Brown School of Business and Leadership, Stevenson University \\ 1525 Greenspring Valley Road, Stevenson, MD, USA \\ Tel: 1-416-777-7777Ｅ-mail: akayes@stevenson.edu
}

\begin{abstract}
This study generated and tested hypotheses regarding the use of upward influence strategies and gender in a US prison system. The present study focused on the upward influence strategies used by male and female employees across ten different prisons. Kipnis and Schmidt's Profile of Organizational Influence Strategies was administered to 201 state employees. The sample was $85 \%$ African American and nearly equally distributed by gender. Data was analyzed for differences among demographic groups. Results show that males use Reason, Bargaining and Coalition strategies; whereas, females use Friendliness strategies more frequently to influence their boss. Implications for research on the choice of influence strategies between genders in a predominately African American population are explored.
\end{abstract}

Keywords: Influence, Management, Organizational behavior 


\section{Introduction}

Understanding influence in organizations is more important than ever. Managers use influence to change the behavior of organizational members, to gain compliance to requests, to increase commitment to difficult projects, and overall to ensure outstanding performance (Yukl, 2002). At the same time, subordinates "manage up" in the organization to gain resources, sell ideas, and ensure the sustainability of their jobs in a competitive climate with limited resources (Gabarro \& Kotter, 1993). Leaders want a better understanding of how to utilize "human capital," and ensure that they accomplish their goals while employees want to understand how to better communicate their ideas, accomplish goals, and engage others for support and resources. Yukl and Falbe (1990) stated that success in influencing superiors, peers, and subordinates is one of the most important factors in determining an employee's success in an organization.

Yet, employees in the same organization and in the same job role with the same level of positional power select significantly different types of influence strategies. As workplace demographics have shifted significantly in the past decade, more women and minorities have moved into key organizational roles, the debate has intensified as to whether there are influence differences between the genders and whether these differences are the same in predominately minority organizations. Researchers suggest that male and female employees have been socialized and exposed to sex role stereotypes which effect their attitudes and behaviors within organizations. These differences in behaviors indicate that gender is a key variable in organizational studies, and in particular studies of influence. This current study seeks to respond to the call in academia for more research studies on gender and influence (Ringer and Boss, 2000; O’Neal, 2004).

Current research on influence strategies has been conducted with primarily nonheterogeneous samples and has been found in such diverse research disciplines as organizational behavior, organizational strategy, psychology, and management. Despite the diversity of research traditions, the concept of gender and racial diversity and its effect on the selection of various influence strategies has not been adequately explored in studies of influence. The majority of research studies centering on influence consist of predominately male samples and fail to report race or ethnicity. Where race is reported, it is almost invariably predominately Caucasian samples. Unraveling differences, especially gender differences in a majority minority population, in the use of upward influence strategies is an area that has not been given adequate attention in the research literature. Prior investigations in the literature have centered on intergroup differences such as simply comparing males with females or comparing African Americans (AA) with Whites. Shuter (1982, 1990) noted that where these comparisons have been fruitful, they are still limited and that we still lack an understanding of behavior patterns within a particular culture or race such as between males and females in a predominately AA group. Subsequently, theory has been formulated with little regard for how females might differ from males in use of influence strategies within a particular racial climate.

This reality juxtaposed with current labor market trends point to a need for researchers to conduct more studies within populations composed of different racial types than the majority 
type. Labor market data illustrates that the gender and racial composition of current organizations are entirely different from even as recently as ten years prior. For instance, census data from the 2000 census reveals that the number of minorities in management positions grew by 830, 000 from 13.0 percent in 1990 to 16.7 percent in 2000 and the number of women in management jobs during this same timeframe increased by one million. This shift in employment and the resulting new demographic composition of contemporary workplaces highlight the critical nature of using gender and race as a lens to study behavioral differences.

Thus, although the topic of gender differences has been explored in a variety of studies, further theoretical and empirical refinement is critical so that findings based on one demographic group (Caucasian males) are not generalized towards all groups. Past influential influence research has used either $85 \%$ or higher Caucasian samples (e.g. Wilson, Lizzio, Zauner, \& Gallois, 2001; Wayne, Liden, Graf, \& Ferris, 1997), not reported the study ethnicity (e.g. Schmidt \& Kipnis,1984;1988; Chacko,1990; Yukl \& Falbe, 1990), or used predominately male samples ranging between 75\%-100\% male (e.g. McFarland, L. A., Ryan, A. M., \& Kriska, S. D., 2002; Emmans, B.J., Munduate, L., Klaver, E., \& Van de Vliert, E., 2003; Wayne, Liden, Graf, \& Ferris,1997; Kipnis \& Schmidt,1984; 1988). This study shows differences between male and female influence strategies using a predominately African American sample that is evenly distributed between males and females. Although individual variables related to influence such as job role, position in the organizational hierarchy and goal achievement orientation have been studied considerably in the influence literature (e.g. Chacko, H., 1990; Deluga, R., 1989; Drory, A., \& Shamir, B., 1988), there are few answers regarding the specific impact of gender on the use of upward influence strategies within an AA group. Researchers have discovered in previous studies that organizational context and job role impacts the choice of influence strategies.

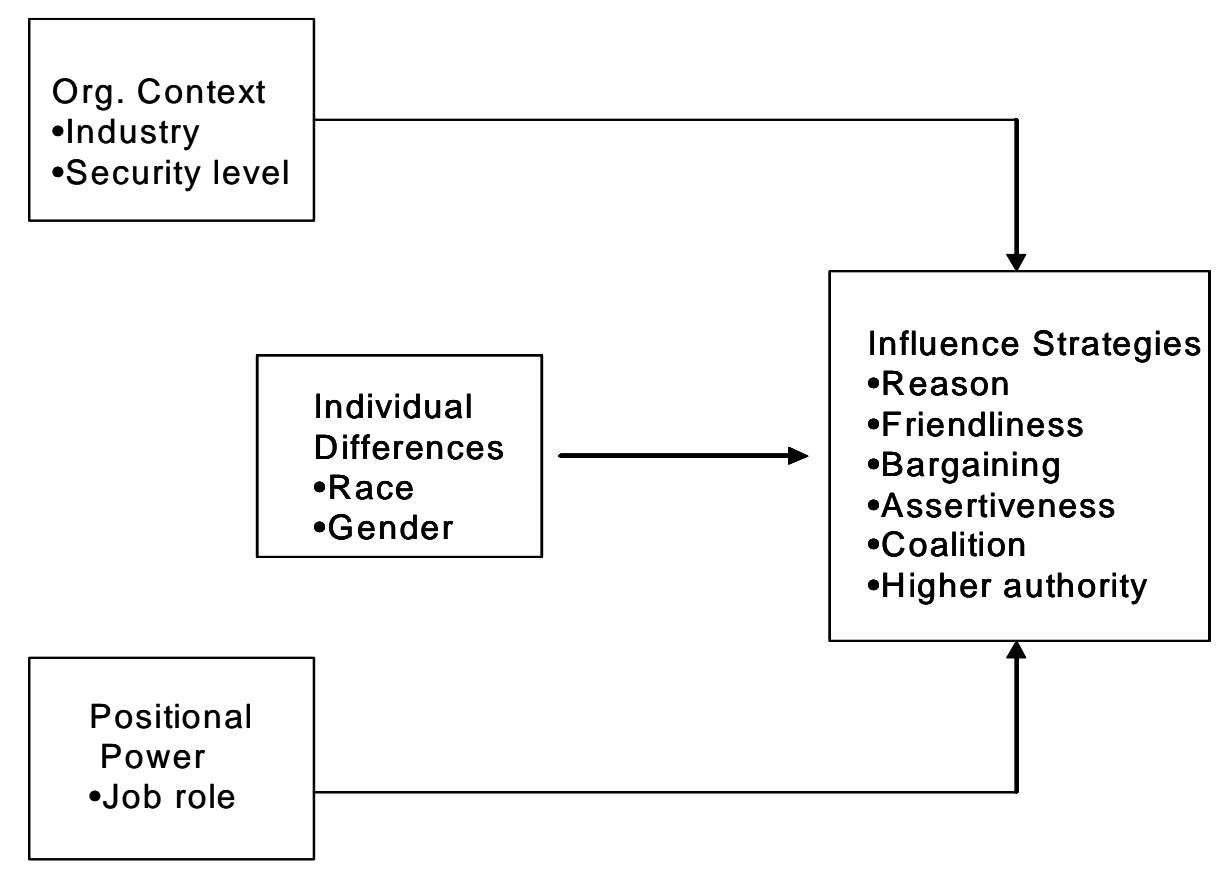

Figure 1. A model of influence strategies impacted by position power, organizational context, and individual factors 
For purposes of this study, job role indicating level of position power and organizational context are held constant. That is, this study centers on workers in the same job role, in the same organization. Figure 1 illustrates the model of this study showing how the organization's context, job role, and individual factors impact the use of influence strategies. The study specifically focuses on individual differences and influence strategies, and accounts for the impact of organizational context and position power by controlling for it. Organizational context is controlled for by: 1) insuring that the sample comes from the same specific industry; 2) comparing differences in influence responses across organizations in the industry; and 3) comparing differences in responses based on organizational security level. Position power is controlled for by: 1) making sure that the sample is in the same job role, and 2) that the job role is described the same on the job description across organizations in the specific industry. The individual factors tested in this study are gender and race.

To further theory and research on the relationship between influence strategies, gender and other demographic variables, I generate hypotheses regarding the use of upward influence strategies. I test the hypotheses in a selected sample comprised of majority of African Americans nearly equal in number of females and males. Results and implications for research are explored.

\section{Theory and Hypotheses}

\subsection{Influence}

Influence describes behaviors for exerting interpersonal power. Over the last 25 years, leadership research, in particular, has shifted its focus of interest on power in the abstract to specific influence behaviors (Yukl, 2002). Where studies of power might investigate more nebulous factors such as motivation that drives the behaviors at work, influence studies examine the actual behaviors displayed at work. This theoretical shift stems from the misalignment of actual behaviors that people exhibit with traditional power classification schemata (Kipnis et al., 1980). Where power increases the motivation to influence someone, influence is the actual process or attempt of changing an attitude or behavior. Some theorists have explained influence as encompassing the notions of compliance and persuasion. That is, compliance is behavior change, and persuasion is cognitive change $(\mathrm{Ng}$, Hung \& Bradac, 1993). Others have defined influence as a shift in probability that a desired result will occur (Gamson, 1974). Research has also served to delineate the differences between power and influence by finding that the type of power an influencer has effects the type of tactic or strategy that they use with their target (Baxter, 1984). That is, influencers with greater power use direct mechanisms for influence and influencers with less power use indirect mechanisms for influence.

Still other theorists have explained influence as any attempt by someone who has a source of power to change a relationship, even if unsuccessful. For the purposes of the present study, influence is defined using Kipnis et al.'s (1980) definition: the attempts that people make at work to change the behavior of their superiors, co-workers, and subordinates. Even with this well developed research stream on the importance of studying influence behavior as opposed to power in general, there is still a shortage of influence studies that account for individual 
differences (e.g. Ringer and Boss, 2000; Yukl, 2002).

\subsection{Upward Influence Strategies}

According to Kipnis and Schmidt (1988):

Influence strategies are the ways in which you make suggestions or requests to your manager in order to obtain results that you want. Any strategy is made up of specific strategies (p. 1).

In particular, influence does not have to have a successful or unsuccessful result, but it includes the notion of intentionality. Influence attempts are deliberate; these attempts are typically studied by examining the direction of the influence in the organization. Most studies that have centered on the target of influence narrowed their approach to either downward influence, mutual influence between peers and within groups, or upward influence. This study selected the use of upward influence to study, because with upward influence, the influencer has less positional power than the target and since position power can be controlled for by selecting a sample from the same job role, the study can focus on individual differences such as gender.

Many different influence strategies exist. While there is theoretical and conceptual overlap among many of the strategies, different theorists use different terms to illustrate the strategies. Strategies are the ways in which specific requests are made between an influencer and a target to cause the target to change a behavior. Because influence is tied to communication and countless studies have determined that males and females communicate differently, upward influence and gender differences are explored but relative power is not a variable considered in this study. Power which is found in an organization's context (Cialdini, Porter, Angle \& Allen, 2003) impacts influence strategy and power found in job role impacts influence strategy, the sample for this study will purposefully be from the same job category, at the same level of positional power hierarchy and from the same unique industry.

Yukl and Tracey (1992) identified nine influence strategies: rational persuasion, consultation, inspirational appeals, personal appeals, ingratiation, exchange, pressure, legitimizing strategies, and coalition strategies. Kipnis, Schmidt and Wilkinson (1980) studied eight strategies: Reason, Coalition, Ingratiation, Bargaining, Assertiveness, Higher Authority, Blocking, and Sanctions. The Blocking strategy was subsequently dropped from Kipnis and Schmidt's research in 1988, and the sanctions strategy is only identified in downward influence attempts.

Kipnis et al. (1980) studied a number of dimensions of influence in various interpersonal relationships, such as those with upward influence, downward influence, and peer-to-peer influence. The present study will focus specifically on the influence strategies defined by Kipnis and Schmidt (1983, 1988; Kipnis et al., 1980)—primarily upward influence, that is, when subordinates try to change the attitudes, beliefs, or behaviors of their superiors. For the purposes of my study, Kipnis et al.'s (1980) definition of upward influence will be used because it is the most widely accepted in the literature. As research has indicated that gender role expectation serve to socialize males and females into certain patterns of behavior in organizations, this study will examine the effects of gender on the selection of upward 
influence strategies. The next section will discuss the specific upward influence strategies according to Kipnis and Schmidt (1980) and its relative importance to gender.

Reason and rational persuasion are strategies that different theorists have defined similarly (e.g., Kipnis et al., 1980; Klein, 1998; Krippendorf, 1995; Mowday, 1979; Yukl \& Falbe, 1990). Yukl and Tracey (1992) believe rational persuasion occurs when "the agent uses logical arguments and factual evidence to persuade the target that a proposal or request is viable and likely to result in the attainment of task objectives" (p. 526). Kipnis and Schmidt (1983) introduced Reason as the use of logical arguments to encourage compliance by the target.

Research on gender role expectations (e.g. Rosenkrantz, Vogel, Bee, Broverman \& Broverman, 1968; Broverman, Vogel, Broverman, Clarkson \& Rosenkrantz, 1972) indicate that males are commonly perceived as having characteristics and engaging in interactions based on competence and rationality, whereas women are commonly expected to engage in interactions based on warmth, friendliness and expressiveness. Although this research on gender role expectations does not specifically investigate the use of upward influence strategies, it does hold implications for understanding behavioral patterns in organizations and for determining some of these patterns of behavior with regard to influence strategies used by males and females based on gender role expectations.

\subsection{Hypotheses}

Hypothesis 1. Males will use Reason as an upward influence strategy more than females. For Kipnis and Schmidt (1983), friendliness involves behaviors designed to strengthen the relationship between the influencer and the target. Friendliness involves behaviors designed to increase the attractiveness of ideas that the influencer introduces (Kipnis \& Schmidt, 1983). Johnson (1976) investigated sex-role stereotypes and concluded that females are seen as more effective when using behaviors such as friendliness, affection and approval. That is, there is strong evidence to indicate that females are encouraged through social sex role stereotypes to engage in upward influence strategy of friendliness if they want to be effective in their influence attempts.

Tannen $(1995,1997,2000)$ elaborates on these sex-role distinctions in her discussion of linguistic style and gender differences. She explains how women have been socialized into using compliments as a way to influence others from a young age. The use of compliments is similar to Kipnis and Schmidt's (1983) description of friendliness. Specifically, Tannen $(1995,1997,2000)$ theorizes that in social structures, males are more likely to take the position of discrediting others or 'putting them down'. Females, in contrast, learn to exchange compliments and build others up, thus increasing the desirability of the social exchange between the female and the female's conversational partner.

Hypothesis 2. Females will use Friendliness as an upward influence strategy more than males. Bargaining, according to Kipnis and Schmidt (1983), offers the promise of resources or benefits in exchange for compliance with the influencer's request. Yukl and Tracey (1992) considered Bargaining as an "exchange" where someone will reciprocate with favors at a 
later point in time. Regan (1971) pioneered this concept in his experimental study of individuals working at an art gallery. He found that when an influencer would offer something like a free drink to a target, the influencer was more likely to sell raffle tickets than when he would not offer a benefit in exchange. This tactic of Bargaining is similar to the process of negotiation, because it relies on the rule of reciprocity.

Babcock \& Lachever (2003) argue that females are not adept at bargaining strategies and will not ask for resources, pay increases and promotions as frequently as men. It follows that women are less inclined than men to use negotiation as a strategy. This is primarily due to socialized gender-role expectations prevalent in western society. If women care more about relationships they will be less likely to upset the relationship based on the selection of negotiations as a strategy for upward influence, rather they would be more inclined to select a relationship-based influence strategy such as Friendliness. Males have been credited throughout many research studies with being more frequent and effective bargainers than women (Watson, 1994).

Hypothesis 3. Males will use Bargaining as an upward influence strategy more than females. Kipnis and Schmidt (1983) described the strategy of assertiveness in negative terms. That is, assertiveness, in their description, includes only those acts such as using anger to force compliance or having face-to-face confrontations. Yukl and Tracey (1992) agreed with this classification of assertiveness as consisting of negative behaviors such as the use of demands and threats to gain compliance. Most social scientists (e.g., Bandura, 1979; Lawson, 2003; Thomas, 1976), however, have made a different distinction between assertiveness and aggressiveness. In these approaches, which differ from Kipnis and Schmidt (1983), and Yuk1 and Tracey (1992), assertiveness (Thomas, 1976) happens when an individual makes a clear statement of desires and preferences with no implication of threat if someone does not comply with the request. Aggressiveness, on the other hand, involves the capacity for pressure and threats (Lawson, 2003).

Wilson, Lizzio, Zauner, and Gallois (2001) presented an approach that offers social rules for managing subordinates who try to take control of managers. This approach included how gender and status affect self-evaluations of managerial effectiveness with "pushy" subordinates. A key finding was that effective response strategies are the same for both males and females. Overall, they found that common rules exist for managers regarding what is socially acceptable for dealing with subordinates who try to assert themselves and disrupt power relationships. This study indicated that males and females do differ in use of upward influence strategies that involve 'pushiness', but that the managers do not differ in how they handle these differences.

Carli (1990) found that males and females differ significantly in their speech and influence patterns. In particular, she found that women tend to be more tentative in their speech patterns than men, while men tend to be more direct in their speech patterns. This is due to a large part that men reported being less influenced by women who speak directly. The sex-role socialization process shapes the speech patterns of women from an early age. Similar to Carli (1990), Tannen (1995), explicates the differences in linguistic signals between males and 
females in terms of 'directness' or 'indirectness'. This differs from Kipnis and Schmidt's definition of assertiveness but is similar to other theorists' (e.g. Bandura, 1979; Lawson, 2003; Thomas, 1976) definitions of assertiveness. Tannen (1995, p. 230) defines indirectness as "the tendency to say what we mean without spelling it out in so many words." This research has indicated that males tend to be more direct and assertive and females tend to be less direct.

Hypothesis 4. Males will use Assertiveness as an upward influence strategy more than females. Coalition occurs when the influencer aligns him- or herself with other employees in order to exert a unified group influence on the target (Kipnis \& Schmidt, 1983). Yukl and Tracey (1992) also used the strategy term coalition but emphasized that this strategy is typically viewed as manipulative. Yukl and Falbe (1992) noted that this strategy is typically used more in upward-influence attempts than in other types of attempts. This is mainly due to the influencer's lacking the power base to utilize another type of strategy.

Tannen (1995) reported research conclusions from many of her studies in organizations that indicated that women did not necessarily promote their ideas through coalitions, and rather they felt that 'doing a good job' was adequate enough in getting promotions, garnering resources or selling ideas. Males, on the other hand, practiced eating lunch with their boss, and boasting about their accomplishments with their peers and selling their ideas in their social networks (Tannen, 1995).

Hypothesis 5. Males will use Coalition as an upward influence strategy more than females.

Kipnis and Schmidt (1983) explained higher authority as the formation of coalitions with a person higher in the organizational structure than the target of influence. The concept of higher authority seems to be least developed in studies of influence. This may be because of the conceptual overlap between coalition formation and alignment with others higher in the organizational structure. Mowday (1979) referred to higher authority as coalition formation with others higher than the influencer in the organizational hierarchy. Yukl and Falbe (1990) also agreed with Mowday (1979) and Kipnis and Schmidt's (1983) description of higher authority. There is conceptual overlap between the construct of Higher Authority and Coalition, which has produced inconclusive results in previous studies. For this reason, this study will not hypothesize around gender and Higher Authority.

\section{Method}

\subsection{Sample}

The sample consisted of 201 prison guards in ten different correctional institutions. The guard sample was fairly evenly split by gender, $53 \%$ were male and $47 \%$ were female. The mean age of the sample was 39 years old; age differences between the group of males and the group of females were not significantly different. The ethnicity of the guards was $84.5 \%$ African American and 14\% Caucasian with no significant differences in gender based on race. The targets for the guards' influence attempts were the prison warden population. The prison warden population was $84 \%$ male and 92\% Caucasian and 5\% African American and 3\% Hispanic. The wardens are equivalent in organizations to top management. That is they are 
the top most managers in the prison system with which the guards have direct contact.

\subsection{The Context}

The present study on the relationship between gender and upward influence strategies does not stand alone in its selection of prisons as a context for organizational studies. Sparks and Bottoms (1995) studied prison systems and utilized Beetham's (1991) criteria for organizational structure and power. Beetham argued that all systems of power relationships in organizations require legitimacy in the structure of the organization. Although Sparks and Bottoms (1995) studied this phenomenon in prisons, they were quick to illustrate in their study that the selection of prison systems does not provide a limited context for organizational studies. Rather, prisons have the same issues of power relations that other organizations have and studies of power relations conducted in prisons apply to other types of organizations.

Likewise, Bean (1999) looked at power and control in the context of prison systems. Bean's study specifically considered how technology in prisons systems serves to control the inmate population as well as the staff members. Bean's interest in power and technology was also expressed in studies of mental hospitals, government offices, and police offices before the studies of prison systems. Further contributing to the understanding of the context of prisons is Drory and Shamir's (1988) study on how organizational variables contribute to job satisfaction among prison guards. In their study, Drory and Shamir concluded that lessons learned in prisons could be generalized to other studies involving "low-prestige" occupations, since prison guards positions are viewed as such. In summary, researchers have been studying power in prison systems as well as in other organizations. The particular correctional institutions were selected based on the evenly distributed number of males and females employed in one type of position, and because it was a majority African American sample.

Because researchers had previously argued that context and position power effect the selection of influence strategies, it was important to control for these potential effects. So, in order to control for possible confounding effects, participants in this study were all in the same job role and in the same type of organizational context. That is, participants all had the same level of positional power relative to each other. They were all in what is considered a 'low status' job, correctional officer, and they all worked in a state correctional institution within the same region.

\subsection{Instrument}

The Profile of Organizational Influence Strategies (POIS) is a well validated, self-report instrument designed to assess the behaviors used by employees when they exert influence on their managers. It consists of six scales that correspond with the six upward influence strategies: Friendliness, Bargaining, Reason, Assertiveness, Higher Authority, and Coalition. Prior research has indicated strong reliability and validity for the POIS. The instrument sorts data into six factors that account for $38 \%$ of the total item variance (Kipnis and Schmidt, 1988). Reliability as measured by alpha coefficients ranged from .65 to .76 .

The POIS was administered in small group testing situations over the course of three weeks 


\section{Al Macrothink}

Journal of Management Research

ISSN 1941-899X

2009, Vol. 1, No. 2: E3

at ten different correctional institutions. The instruments were administered in pencil-and-paper format. Six scores were derived from the POIS: Friendliness, Bargaining, Reason, Assertiveness, Higher Authority, and Coalition. Although this study did not generate hypotheses around Higher Authority, data was collected because it is part of the standard validated POIS.

Table 1. Security Levels of Sample by Organization

No. of

Organization

s Associated

Security with Security

\begin{tabular}{lll} 
Level & Level & Definition of security level classification \\
\hline Maximum & 1 & It is the location for the Death Row population. Long
\end{tabular}
Term; Single, multiple, \& Life + sentences. No disruptive behavior for at least past 24 months prior to consideration for a transfer to any less-secure facility.

Moderate $1 \quad$ Long Term; Single, multiple, \& Life + sentences. No disruptive behavior for at least past 24 months prior to consideration for a transfer to any less-secure facility.

Medium $5 \quad$ Single, multiple, \& Life + sentences must have served 20 consecutive years on sentence. No disruptive behavior for at least past 24 months prior to consideration for a transfer to any less-secure facility.

Low 3 No Escape History within past 5 years. Single Life sentences must have reached their Parole Eligibility Date (PED).No disruptive behavior for at least past 24 months prior to consideration for a transfer to any less-secure facility

Because data was collected from ten different organizations, which differed in security level from minimum to maximum security as shown in Table 1, ANOVA's revealed that there were no significant differences in gender or selection of upward influence strategies based on security level. 
Table 2. Comparison of Influence Strategies and Security Level

\begin{tabular}{|c|c|c|c|c|c|}
\hline & $\begin{array}{l}\text { Sum of } \\
\text { Squares }\end{array}$ & $\mathrm{df}$ & $\begin{array}{l}\text { Mean } \\
\text { Square }\end{array}$ & $\mathrm{F}$ & Sig. \\
\hline \multirow[t]{3}{*}{ Friendliness } & $\begin{array}{l}\text { Between } \\
\text { Groups }\end{array}$ & 1.435 & 3 & .478 & .724 \\
\hline & $\begin{array}{l}\text { Within } \\
\text { Groups }\end{array}$ & 130.111 & 197 & .660 & \\
\hline & Total & 131.545 & 200 & & \\
\hline \multirow[t]{3}{*}{ Bargaining } & $\begin{array}{l}\text { Between } \\
\text { Groups }\end{array}$ & .898 & 3 & .299 & .374 \\
\hline & $\begin{array}{l}\text { Within } \\
\text { Groups }\end{array}$ & 157.854 & 197 & .801 & \\
\hline & Total & 158.753 & 200 & & \\
\hline \multirow[t]{3}{*}{ Reason } & $\begin{array}{l}\text { Between } \\
\text { Groups }\end{array}$ & 3.779 & 3 & 1.260 & 1.245 \\
\hline & $\begin{array}{l}\text { Within } \\
\text { Groups }\end{array}$ & 199.227 & 197 & 1.011 & \\
\hline & Total & 203.006 & 200 & & \\
\hline \multirow[t]{3}{*}{ Assertiveness } & $\begin{array}{l}\text { Between } \\
\text { Groups }\end{array}$ & 2.808 & 3 & .936 & 1.450 \\
\hline & $\begin{array}{l}\text { Within } \\
\text { Groups }\end{array}$ & 127.162 & 197 & .645 & \\
\hline & Total & 129.970 & 200 & & \\
\hline \multirow[t]{3}{*}{$\begin{array}{l}\text { Higher } \\
\text { Authority }\end{array}$} & $\begin{array}{l}\text { Between } \\
\text { Groups }\end{array}$ & .306 & 3 & .102 & .133 \\
\hline & $\begin{array}{l}\text { Within } \\
\text { Groups }\end{array}$ & 150.866 & 197 & .766 & \\
\hline & Total & 151.173 & 200 & & \\
\hline \multirow[t]{2}{*}{ Coalition } & $\begin{array}{l}\text { Between } \\
\text { Groups }\end{array}$ & .763 & 3 & .254 & .202 \\
\hline & $\begin{array}{l}\text { Within } \\
\text { Groups }\end{array}$ & 248.709 & 197 & 1.262 & \\
\hline
\end{tabular}

*Significance at .05 level

**Significant at .01 level

In addition to controlling for organizational context, job role was also controlled for. The same job description for correctional officer is used across all ten correctional organizations. Tenure differences in the same job role were tested and there were no significant differences. Table 3 shows how there were no significant relationships between years worked and influence strategies. 
Table 3.Years Worked and Influence Strategies

\begin{tabular}{|c|c|c|c|c|c|c|}
\hline & & $\begin{array}{l}\text { Sum of } \\
\text { Squares }\end{array}$ & $\mathrm{df}$ & $\begin{array}{l}\text { Mean } \\
\text { Square }\end{array}$ & $\mathrm{F}$ & Sig. \\
\hline \multirow[t]{3}{*}{ Friendliness } & $\begin{array}{l}\text { Between } \\
\text { Groups }\end{array}$ & 1.641 & 4 & .410 & .614 & .653 \\
\hline & $\begin{array}{l}\text { Within } \\
\text { Groups }\end{array}$ & 118.905 & 178 & .668 & & \\
\hline & Total & 120.546 & 182 & & & \\
\hline \multirow[t]{3}{*}{ Bargaining } & $\begin{array}{l}\text { Between } \\
\text { Groups }\end{array}$ & .809 & 4 & .202 & .249 & .910 \\
\hline & $\begin{array}{l}\text { Within } \\
\text { Groups }\end{array}$ & 144.648 & 178 & .813 & & \\
\hline & Total & 145.457 & 182 & & & \\
\hline \multirow[t]{3}{*}{ Reason } & $\begin{array}{l}\text { Between } \\
\text { Groups }\end{array}$ & 8.085 & 4 & 2.021 & 2.039 & .091 \\
\hline & $\begin{array}{l}\text { Within } \\
\text { Groups }\end{array}$ & 176.494 & 178 & .992 & & \\
\hline & Total & 184.579 & 182 & & & \\
\hline \multirow[t]{3}{*}{ Assertiveness } & $\begin{array}{l}\text { Between } \\
\text { Groups }\end{array}$ & .947 & 4 & .237 & .355 & .840 \\
\hline & $\begin{array}{l}\text { Within } \\
\text { Groups }\end{array}$ & 118.808 & 178 & .667 & & \\
\hline & Total & 119.755 & 182 & & & \\
\hline \multirow[t]{3}{*}{$\begin{array}{l}\text { Higher } \\
\text { Authority }\end{array}$} & $\begin{array}{l}\text { Between } \\
\text { Groups }\end{array}$ & .413 & 4 & .103 & .132 & .971 \\
\hline & $\begin{array}{l}\text { Within } \\
\text { Groups }\end{array}$ & 139.420 & 178 & .783 & & \\
\hline & Total & 139.834 & 182 & & & \\
\hline \multirow[t]{3}{*}{ Coalition } & $\begin{array}{l}\text { Between } \\
\text { Groups }\end{array}$ & 1.383 & 4 & .346 & .276 & .893 \\
\hline & $\begin{array}{l}\text { Within } \\
\text { Groups }\end{array}$ & 222.707 & 178 & 1.251 & & \\
\hline & Total & 224.090 & 182 & & & \\
\hline
\end{tabular}

*Significance at .05 level

**Significant at .01 level

Ethnicity of the sample was majority African American. This study did not hypothesize that there would be significant differences between the AA correctional officers and the Caucasian officers in influence strategies, rather the study examined gender and influence in a majority AA population. Possible influence differences based on ethnicity were calculated and no significant results were found. Table 4 shows the results. 
Table 4.Comparison of Ethnicity and Influence Strategies

\begin{tabular}{|c|c|c|c|c|}
\hline & $\begin{array}{l}\text { Sum of } \\
\text { Squares }\end{array}$ & df & $\begin{array}{l}\text { Mean } \\
\text { Square }\end{array}$ & $\mathrm{F}$ \\
\hline \multirow[t]{3}{*}{ Friendliness } & $\begin{array}{l}\text { Between } \\
\text { Groups }\end{array}$ & .278 & 1 & .278 \\
\hline & $\begin{array}{l}\text { Within } \\
\text { Groups }\end{array}$ & 120.990 & 184 & .658 \\
\hline & Total & 141.347 & 185 & \\
\hline \multirow[t]{3}{*}{ Reason } & $\begin{array}{l}\text { Between } \\
\text { Groups }\end{array}$ & 6.588 & 1 & 6.588 \\
\hline & $\begin{array}{l}\text { Within } \\
\text { Groups }\end{array}$ & 198.813 & 184 & 1.081 \\
\hline & Total & 205.402 & 185 & \\
\hline \multirow[t]{3}{*}{ Assertiveness } & $\begin{array}{l}\text { Between } \\
\text { Groups }\end{array}$ & 4.390E-02 & 1 & .294 \\
\hline & $\begin{array}{l}\text { Within } \\
\text { Groups }\end{array}$ & 124.296 & 184 & .676 \\
\hline & Total & 124.340 & 185 & \\
\hline \multirow[t]{3}{*}{$\begin{array}{l}\text { Higher } \\
\text { Authority }\end{array}$} & $\begin{array}{l}\text { Between } \\
\text { Groups }\end{array}$ & $9.190 \mathrm{E}-04$ & 1 & .975 \\
\hline & $\begin{array}{l}\text { Within } \\
\text { Groups }\end{array}$ & 170.777 & 184 & .928 \\
\hline & Total & 170.778 & 185 & \\
\hline \multirow[t]{3}{*}{ Coalition } & $\begin{array}{l}\text { Between } \\
\text { Groups }\end{array}$ & 2.468 & 1 & 2.468 \\
\hline & $\begin{array}{l}\text { Within } \\
\text { Groups }\end{array}$ & 194.280 & 184 & 1.056 \\
\hline & Total & 196.749 & 185 & \\
\hline
\end{tabular}

*Significance at .05 level

**Significant at .01 level

\section{Results}

The POIS indicated strong reliability on all six scales: Friendliness $(\alpha=.83)$, Bargaining $(\alpha=.90)$, Reason $(\alpha=.87)$, Assertiveness $(\alpha=.89)$, Higher Authority $(\alpha=.88)$, and Coalition $(\alpha=.83)$. The means and standard deviations for each of the two groups on the six POIS scales are presented in Table 5. Mean scores were analyzed for gender differences.

Overall, the males reported higher use of Bargaining, Reason and Coalition. The females reported higher use of Friendliness. 


\section{Ml Macrothink}

Table 5. Comparison of Male and Female Prison Guards on the Profile of Organizational Influence Strategies

\begin{tabular}{llccc}
\hline \multicolumn{1}{c}{ Variable } & & Sex & & \\
SD & & & & \\
\hline Friendliness & Male & 2.74 & .73 & n.s. \\
& Female & 3.04 & .90 & $2.77^{* *}$ \\
Bargaining & Male & 2.17 & .86 & $2.03^{*}$ \\
& Female & 1.91 & .89 & n.s. \\
Reason & Male & 3.08 & .90 & $2.76^{* *}$ \\
& Female & 2.67 & 1.06 & n.s. \\
Assertiveness & Male & 2.01 & .75 & n.s. \\
& Female & 2.03 & .83 & n.s. \\
Higher Authority & Male & 1.99 & .79 & n.s. \\
& Female & 1.94 & .92 & n.s. \\
Coalition & Male & 2.67 & .99 & 2.26* \\
& Female & 2.33 & 1.03 & n.s. \\
\hline
\end{tabular}

*Significance at .05 level

**Significant at .01 level

The first hypothesis, stating that males will be more likely than females to exert

upward influence strategies based on Reason, was supported. The mean score for males that reported the use of Reason as an upward influence strategy was significantly higher $(t=2.76$, $p<.01)$ than the mean scores for females.

The second hypothesis, stating that females will be more likely than males to exert upward influence strategies based on Friendliness, was supported. The mean score for females that reported the use of Friendliness as an upward influence strategy was significantly higher $(t=$ $2.77, p<.01)$ than the mean score for males.

The third hypothesis, stating that males will be more likely than females to exert upward influence strategies based on Bargaining, was also supported. The mean score for males that reported the use of Bargaining was significantly higher $(t=2.03, p<.05)$ than the mean score for females.

The fourth hypothesis, stating that males will be more likely than females to exert upward influence strategies based on Assertiveness, was not supported. The mean score for both females ( $M=2.03)$ and males $(M=2.01)$ was the second lowest, behind the use of Higher Authority of all of the reported upward influence strategies.

The fifth hypothesis males will be more likely than females to exert upward influence strategies based on Coalition, was also supported. The mean score for males $(t=2.06, p$ $<.05$ ) that reported the use of Coalition was significantly higher than the mean score for females.

\section{Discussion}


This study indicated that there are gender differences in the types of upward influence strategies that are selected based on gender and contributes to our understanding of how different sexes influence their environment. Results revealed that males more than females used the upward influence strategies of Bargaining, Reason and Coalition. In comparison, females were more likely to use Friendliness.

Results indicated no significant differences within gender groups based on time worked in the organization. Research on sex-role stereotypes indicates that there should have been differences in the manner in which females or males exert upward influence over time (Broverman, Bogel, Broverman, Clarkson, \& Rosenkrantz, 1972). For instance, officers should differ on their use of strategies when they first start working in the organization from the manner in which they exert upward influence after five or ten years of tenure in the organization. This difference in behavior over time might indicate that employees succumb to sex-role stereotypes after a period of time working in an organization with strict role stereotypes. However, there were no significant differences within gender groups between tenure of 0-3 years, versus 5-10 years of tenure with the organization. This might indicate that females and males have been socialized at an early age into definitive patterns of behavior that include how they 'manage up' at work prior to their entry into the organization.

The hypothesis that males would use Assertiveness more than females was not supported. There are two possible reasons for this. One reason is that the construct of Assertiveness as defined by Kipnis and Schmidt is similar to aggression described by other researchers. For this reason, this study may have been measuring use of aggression rather than the use of assertiveness. Research on differences in male and female communication patterns centers on assertiveness more than aggression. Although this is a possibility, a second reason seems more plausible.

The second reason for the lack of support for the hypothesis may stem from the type of organization and organizational culture. Prisons are conceived of as total institutions (Goffman, 1962) or bureaucracies and may not be conducive for employees who make demands of their boss. Following strict role expectations, including gender role expectations, is supported, specifically, in bureaucratic organizations (Weber, 1946). Organizations which have strict hierarchies, such as correctional facilities, have informal and formal rules about the exchange of information among subordinates and bosses. Thus the use of demands and aggression by both females and males would be inappropriate. Employees upward influence attempts are rational and based on informal and formal rules, not aggression.

The three chief limitations of this study are generalizability, history threats and ethnicity of the wardens. First, the study does have implications for understanding the way, in which male and female employees from a predominately African American sample "manage up" in organizations, but the study does not definitively predict how patterns of behavior will emerge in all organizations. Furthermore, although the context of prisons has been used for studies of organizational behavior, those studies may be more applicable to other types of total institutions such as government agencies, mental institutions, hospitals, schools, and 
military settings.

Second, this particular study experienced several history threats or unanticipated events that occurred around the time of the study. One example was a hurricane had just damaged a large geographical area in which several of the correctional institutions were located. The aftermath of the hurricane increased the workloads and stress of the officers. Five factors in particular occurred during the course of study: (1) officers were working increased overtime shifts; (2) inmates were being transferred by the hundreds to one facility in particular that was filled beyond maximum capacity; (3) these transfers, for security reasons, were kept secret until an hour or so before the movement and officers were not involved in the decision making process; (4) one of the facilities underwent a change in leadership; and (5) there were reduced staff due to vacancies. These events are all threats to the internal validity of the study because of their potential for affecting how officers interacted with their boss, the frequency of interaction with their boss, and the officers' general disposition toward their boss.

The third limitation is the difference in ethnicity between correctional officers and top management. The correctional officer sample was 85\% African American while the race of management in the organizations, the wardens, was primarily Caucasian. One of the characteristics of a total institution is inequality. In this sample of organizations, there are significant racial differences between those in control of the organization, the wardens, and the workers, or correctional officers. Kipnis (1996) theorized that climates where management and employees differ on measures of diversity such as "culture, class, race, background, gender and work ideologies" (p. 48) may experience increased management control of employees whom management should trust. By the same token, as top management distrusts employees who are different from themselves, employees may also distrust top management. Therefore, there may be a confounding relationship between ethnicity and influence and trust. This limitation in particular holds an opportunity for future research.

\section{Implications}

Future studies that examine influence interactions, should also consider the ethnicity of the target (the boss) and other individual factors in the relationship such as trust. Trust has been shown to effect bottom line outcomes such as satisfaction, turnover intent and profitability. Any relationship between trust and influence would be timely and well received.

Another implication for future studies is the issue of net payoff. That is, research has indicated that influence strategies can be sorted into coercive and non-coercive strategies. Those strategies that are considered coercive, such as the use of assertiveness or higher authority could be both impacted by and impact the overall health of the organization. Research that examines the extent to which the use of coercive influence strategies are damaging to individual outcomes such as interpersonal relationships and job satisfaction and organizational outcomes such as organizational commitment and organizational citizenship behavior would be well received. By the same token, studies which examine low coercive patterns of influence and the link to positive individual and organizational outcomes would be equally relevant. 
This study generated theoretical implications for the cause of influence behavior in organizations in majority AA populations. Equally valuable is translating the theoretical implications to practical considerations for managers in organizations. The first implication for management is that influence behaviors such as seeking resources, selling ideas and convincing others to pursue goals is an organizational reality brought on by an increase in performance pressure. When groups, such as those confined to a low status job role, do not have the formal power to change people's attitudes and behavior, they resort to other strategies to insure success. The two implications for managers are awareness and management methods. Management can be aware that workers, who may differ from themselves in gender and racial composition, are under performance pressure often without the necessary formally sanctioned resources to accomplish their goals. Management methods should focus on inclusion. In this study, top management was predominately Caucasian, while the influencers were predominately AA. Methods that promote open communication and empowerment when these differences are present may take the place of alternative behaviors such as influence. Management methods that encourage a wider array of organizationally sanctioned behaviors may lead to improved success. If organizational members are confined to the use of gendered behaviors, it may limit their overall effectiveness in the eyes of management.

Despite its limitations, this study furthers understanding of upward influence between the sexes in the public sector. This study has a number of strengths, including a diverse sample in the same job role from ten different prisons; an interesting organizational context that sheds light on patterns of human interaction in a total institution or absolute bureaucracy; and a focus on gender differences and influence which is a key topic in studies of organizations. From a research perspective, the greatest contribution of this study is that it links gender differences and upward influence strategies to better explain the process of interaction between subordinates and bosses in organizations. The findings show a clear pattern of differences across five different upward influence strategies. Further, the study was conducted with a predominately African American sample helps to further refine previous theoretical findings that have relied heavily on primarily Caucasian samples in explaining patterns of behaviors in organizations.

\section{References}

Babcock, L. \& Lachever, S. (2003). Women don't ask: Negotiation and the gender divide. Princeton, NJ: Princeton Press.

Bandura, A. (1979). The social leaning perspective: Mechanisms of aggression. In A. Toch(Ed.), Psychology of crime and criminal justice (pp. 298-336). New York: Holt,Rinehart \& Winston.

Bean, P. (1999). Technology and criminal justice. International Review of Law, 13, 365- 371.

Broverman, I., Bogel, S., Broverman, D., Clarkson, F., \& Rosenkrantz, P. (1972). Sex-role stereotypes: A current appraisal. Journal of Social Issues, 2, 59-78.

Carli, L. L. (1990). Gender, language, and influence. Journal of Personality and Social 
Psychology, 56, 565-576.

Chacko, H. E. (1990). Methods of upward influence, motivational needs, and administrators' perceptions of their supervisors' leadership styles. Group and Organization Studies, 15, 253-265.

Deluga, R. (1989). Employee influence strategies as possible stress coping mechanisms for role conflict and role ambiguity. Basic and Applied Social Psychology, 10, 4, 329 - 335.

Drory, A., \& Shamir, B. (1988). Effects of organizational and life variables on job satisfaction and burnout. Group and Organization Studies, 13, 441-455.

Dulebohn, J. H. (1999). The role of influence strategies in perceptions of performance evaluations' fairness. Academy of Management Journal, 42, 288-303.

Emmans, B.J., Munduate, L., Klaver, E., \& Van de Vliert, E. (2003). Constructive consequences of leaders forcing influence styles. Journal of Applied Psychology, 52, 1, 35-54.

Gabarro, J. J. \& Kotter, J. P. (1993). HBR classic: Managing your boss. Harvard Business Review, 72, 150-157.

Gamson, W. A. (1974). Power and probability. In J. Tedeschi (Ed.), Perspectives on social power (pp. 19-33). Chicago: Aldine Publishing Company.

Goffman, E. (1962). Asylums: Essays on the social situation of mental patients and other inmates. Chicago: Aldine Publishing Company.

Johnson, P. (1976). Women and power: Toward a theory of effectiveness. Journal of Social Issues, 33, 3, $99-110$.

Kacmar, M. K. (1996). Subordinate reactions to the use of impression management strategies and feedback by the supervisor. Journal of Managerial Issues, 8, 35 -54.

Kipnis, D. \& Schmidt, S. M. (1983). An influence perspective on bargaining within organizations. In M. H. Bazerman \& R. J. Lewicki (Eds.), Negotiating in organizations (pp. 179 - 210). Beverly Hills: Sage Publications.

Kipnis, D. \& Schmidt, S. M. (1988). Upward influence styles: Relationship with performance evaluation. Administrative Science Quarterly, 33, 528 - 543.

Kipnis, D. Schmidt, S. M., \& Wilkinson, I. (1980). Intraorganizational influence strategies: Explorations in getting one's way. Journal of Applied Psychology, 65(4), 440 - 452.

Kipnis, D. \& Vanderveer, R. (1971). Ingratiation and the use of power. Journal of Personality and Social Psychology, 17, 280 -286.

Klein, G. (1998). Source of power: How people make decisions. Cambridge: The MIT Press.

Krippendorf, K. (1995). Undoing power. Critical Studies in Mass Communication, 12, 101 126. 


\section{Macrothink

Lawson, D. (2003). Incidence, explanations, and treatment of partner violence. Journal of Counseling and Development, 81, 19 - 33.

Lee, D. R. \& Sweeney, P. J. (2001). An assessment of influence strategies used by project managers. Engineering Management Journal, 13, 16 - 24.

McFarland, L. A., Ryan, A. M., Kriska, S. D. (2002). Field study investigation of applicant use of influence tactics in a selection interview. Journal of Psychology, 136, $383-400$.

Mowday, R. T. (1979). Leader characteristics: Self-confidence, and methods of upward influence in organizational decision situations. Academy of Management Journal, 22, 709 725 .

Ng Hung, S. \& Bradac, J. J. (1993). Power in language: Verbal communication and social influence. Newbury Park: Sage Publications.

Ragins, B. E. \& Sundstrom, E. (1989). Gender and power in organizations: A longitudinal study. Psychological Bulletin, 105, 51 - 88.

Regan, R. T. (1971). Effects of favor and liking on compliance. Journal of Experimental Social Psychology, 7, 627 - 639.

Ringer, R. C. \& Boss, W. (2000). Hospital professionals' use of upward influence strategies. Journal of Managerial Issues, 12, 92 - 108.

Rosenkrantz, P., Vogel, S. Bee, H., Broverman, I., \& Broverman, D.E. (1968). The multiplicity of personal identity. Review of Personality and Social Psychology, 68, 87 - 113.

Schilit, W. K., \& Locke, E. (1982). A study of upward influence in organizations. Administrative Science Quarterly, 27, 304 - 316.

Schuter, R. (1982). Initial interaction of American blacks and whites in interracial and interracial interaction. Journal of Social Psychology, 117, 45 - 52.

Schuter, R. (1990). The centrality of culture. Southern Communication Journal, 3, 237 - 249.

Sparks, J. R. \& Bottoms, A. E. (1995). Legitimacy and order in prisons. British Journal of Sociology, 46, 45 - 61.

Tannen, D. (1995). The power of talk: Who gets heard and why. Harvard Business Review 73, 5.

Tannen, D. (1997). Gender and language in the workplace. In Ruth Wodak (Ed.) Gender and Discourse, (pp. 81-105). London: Sage.

Tannen, D. (2000). Indirectness at work. In Joy Peyton, Peg Griffin, Walt Wolfram and Ralph Fasold (Eds.), Language in action: New studies of language in society, (pp.189-212). Cresskill, NJ: Hampton Press.

Thomas, K. (1976). Conflict and conflict management. In M. Dunnette (Ed.), Handbook of industrial and organization psychology. Chicago, IL: Rand McNally. 
Watson, C. (1994). Gender differences in negotiating behavior and outcomes: Fact or artifact. In A. Taylor \& J. B. Miller (Eds.), Conflict and gender (pp. 191- 210). Creskill, NJ: Hampton Press.

Weatherall, A. (1998). Women and men in language. Human Communication Research, 25, $275-292$.

Weber, M. (1946). Essays in sociology. Oxford University Press.

Wilson, K. L., Lizzio, A. J., Zauner, S., \& Gallois, C. (2001). Social rules for managing attempted interpersonal domination in the workplace: Influence of status and gender. Sex Roles, 44, 129 - 154.

Yukl, G. (2002). Leadership in organizations. Upper Saddle River, New Jersey: Prentice Hall.

Yukl, G., \& Falbe, C. M. (1990). Influence attempts in upward, downward, and lateral influence attempts. Journal of Applied Psychology, 75, 132 -140.

Yukl, G.,\& Tracey, B. (1992). Consequences of influence strategies used with subordinates, peers and the boss. Journal of Applied Psychology, 77, 525 - 535. 